gated his son to act as his representative and as field leader of the Kenyan team, which set off in June 1967. In the course of that expedition, again while travelling by air, Richard came to see the fossiliferous sediments on the eastern side of Lake Turkana that were to prove of such immense significance.

The fossil wealth of the Lake Turkana deposits, subsequently revealed by inspection on the ground, convinced the National Geographic Society that an expedition to the area would be a rewarding enterprise. This expedition, organized and

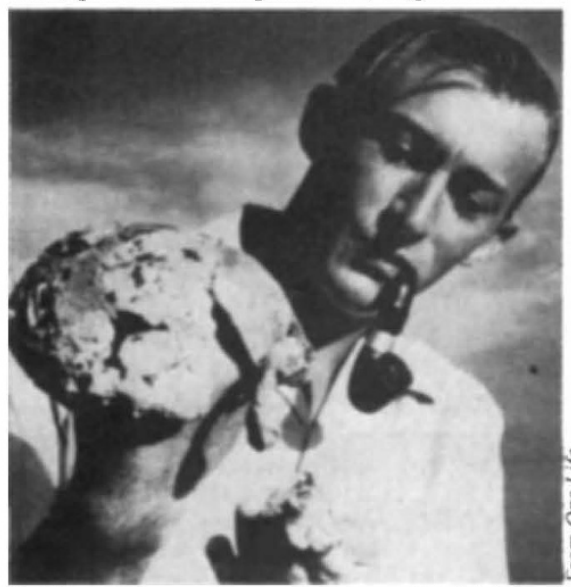

Subjects of controversy - a youthful Richard Leakey with the 1470 skull.

led by Richard, made its headquarters at Allia Bay, and proved fruitful beyond hope - the haul of fossils was so great that each year since 1968 there has been scientific work in the area and a permanent establishment is based there.

On the second expedition of 1969 the base camp was moved to a sandy peninsula ten miles upshore known as Koobi Fora. On this expedition the young geologist, Kay Behrensmeyer, was the first to find very early stone artefacts weathering from a deposit of volcanic ash, or tuff, which could be dated. This volcanic horizon, known as the Kay Behrensmeyer Site (KBS) tuff, became the centre of a dating controversy, crucially affecting the interpretation of the fossil hominids shortly to be found at Koobi Fora. The first of these specimens, found in July 1969, was a particularly beautiful skull of a robust australopithecine. Further discoveries followed but the most significant was the 1470 skull found in July 1972 by the Kenyan, Bernard Ngeneo. This was clearly not the skull of an australopithecine: its cranial capacity was about $775 \mathrm{ml}$ and, on the initial dating of the KBS tuff, it was thought to be more than 2.6 million years old. The announcement of 1470 and Richard's interpretation of it as belonging to Homo of such great antiquity sparked a lively controversy. It was the palaeontologist Basil Cooke who showed in 1975 that, on the evidence of fossil pigs from Koobi Fora, the KBS tuff could not be as old as first thought. Revised dating estimates put the age of the controversial 1470 skull at about 1.9 million years, where its advanced features can be accommodated with greater confidence.

Perhaps the most striking feature of the personality portrayed in this autobiography is the driving ambition and energy behind the achievements, sharpened perhaps by the realization that Richard's life could well be a short one. In 1969, aged 25 , doctors told him that his kidneys could not last more than ten years, and by 1979 his health had severely deteriorated. The situation was saved by the transplant of a kidney donated by his younger brother Phillip - this was the end of "one life", the title of the book, and beginning of another.

One of Richard's ambitions was to become Executive Director of Kenya's National Museum. But how to do it at the age of 23 and without the benefit of university training? His strategy was based on the observation that government support for the museum was low and that there was dissatisfaction with the fact that Kenyan nationals were not being trained for senior positions. Richard set about raising money, establishing an organization known as the Kenya Museum Associates with its own board of directors, which included prominent Kenyan personalities, and a formal constitution. By virtue of his position as Director of the Kenya Museum Associates, Richard attended museum board meetings and became active in the museum's administration.

The next step was to persuade a highplaced civil servant to give the board an ultimatum: either it took on Richard Leakey and made efforts to Kenyanize senior posts or else all government funding would cease! Apprehensively the museum board offered Richard a post of Administrative Officer; but rather than accept it, he insisted that it be upgraded to Administrative Director with full responsibility for the administration for the entire National Museum. The board seemed to know when it was beaten and agreed to the demand, allowing Richard to take up the post from October 1968.

This coup d'etat approach to problems in one's life may be effective, but it tends to generate conflict and animosity. Richard was well aware of such effects, regarding them as unfortunate but unavoidable byproducts of one's passage through a peopled world. Such matters aside, the life described in this autobiography is one of exuberant excitement and adventure. It tells of catching lions in the suburbs of Nairobi as a schoolboy; of narrow escapes from hungry crocodiles on the Omo River; of riding camels in search of fossils at Koobi Fora; and of finding spectacular skulls of immense interest to world science. More than this, the book illuminates a personality that has become known to millions through television programmes such as The Making of Mankind.

C.K. Brain is Director of the Transvaal Museum in Pretoria, South Africa.

\section{Measured moments}

\author{
Barry Cox
}

\section{Timescale: An Atlas of the Fourth}

Dimension. By Nigel Calder.

Chatto \& Windus/Viking: 1984. Pp.288. f12.95, \$19.95.

NigEL Calder's unusual book provides a complete chronology of the world, starting with the first microsecond some 13,500 million years ago, and ending with the Space Shuttle.

It would obviously have been impossibly dull to do this only as a consecutive narrative, and Calder has sensibly taken several different but complementary approaches. The main section of the book (nearly 100 pages) is taken up by the "Narrative and Timescale". Because both the extent of our knowledge and the intensity of our interest steadily increase through time, Calder uses a logarithmic scale. So, after mention of the first million years that encompassed the birth of the Universe, each double-page spread deals with progressively smaller bites from the cake of time, starting with 3,500 million years and passing through 6,000 years to end with the past eight years. (But the author has not allowed himself to become the slave of this format, for the text runs continuously from spread to spread.)

Though the narrative that accompanies this roller-coaster ride through history is always clear and coherent, it can inevitably make only passing reference to many significant events. Calder has therefore added a reference index, about 100 pages long, in which topics are elaborated or added. This includes over 900 entries, most of which are given dates for their origin or extent in time, and are cross-referenced e.g. blue-green algae (bacteria) est. 1600 Myr, see life on Earth; stromatolites. The entries range in length from one line to three pages, and many provide useful references for further reading.

Calder's third approach is to give eight pages of maps, which show the various stages of continental drift, the climate and geography of the Ice Age maximum, and the dispersal patterns of the races, languages and techniques of mankind.

In the sixty-page introductory "Overview", Calder puts the whole chronological enterprise into the historical perspective of its discovery. This, too, is written in a stimulating and provocative style - for example, he suggests that the master of the planet is grass, which has seduced its human slaves into cultivating, protecting and feeding it. We are, then, the puppets not only of our selfish genes, but also of our selfish grains. Calder's book is both enjoyable and useful - not a common combination.

Barry Cox is Head of the Zoology Department at King's College, University of London. 